\title{
Pathways to Ultra-Low Platinum Group Metal Catalyst Loading in Proton Exchange Membrane Electrolyzers
}

\author{
${ }^{\ddagger}$ Katherine E. Ayers ${ }^{a}$, Julie N. Rennera, Nemanja Danilovic ${ }^{a}$, Jia X. Wang ${ }^{b}$, Yu Zhang ${ }^{b}$, \\ Radenka Maric ${ }^{c}$, Haoran $\mathrm{Yu}^{\mathrm{c}}$ \\ a Proton OnSite, 10 Technology Drive, Wallingford, CT 06492, USA \\ ${ }^{b}$ Department of Chemistry, Brookhaven National Laboratory, Upton, NY 11973, USA
}

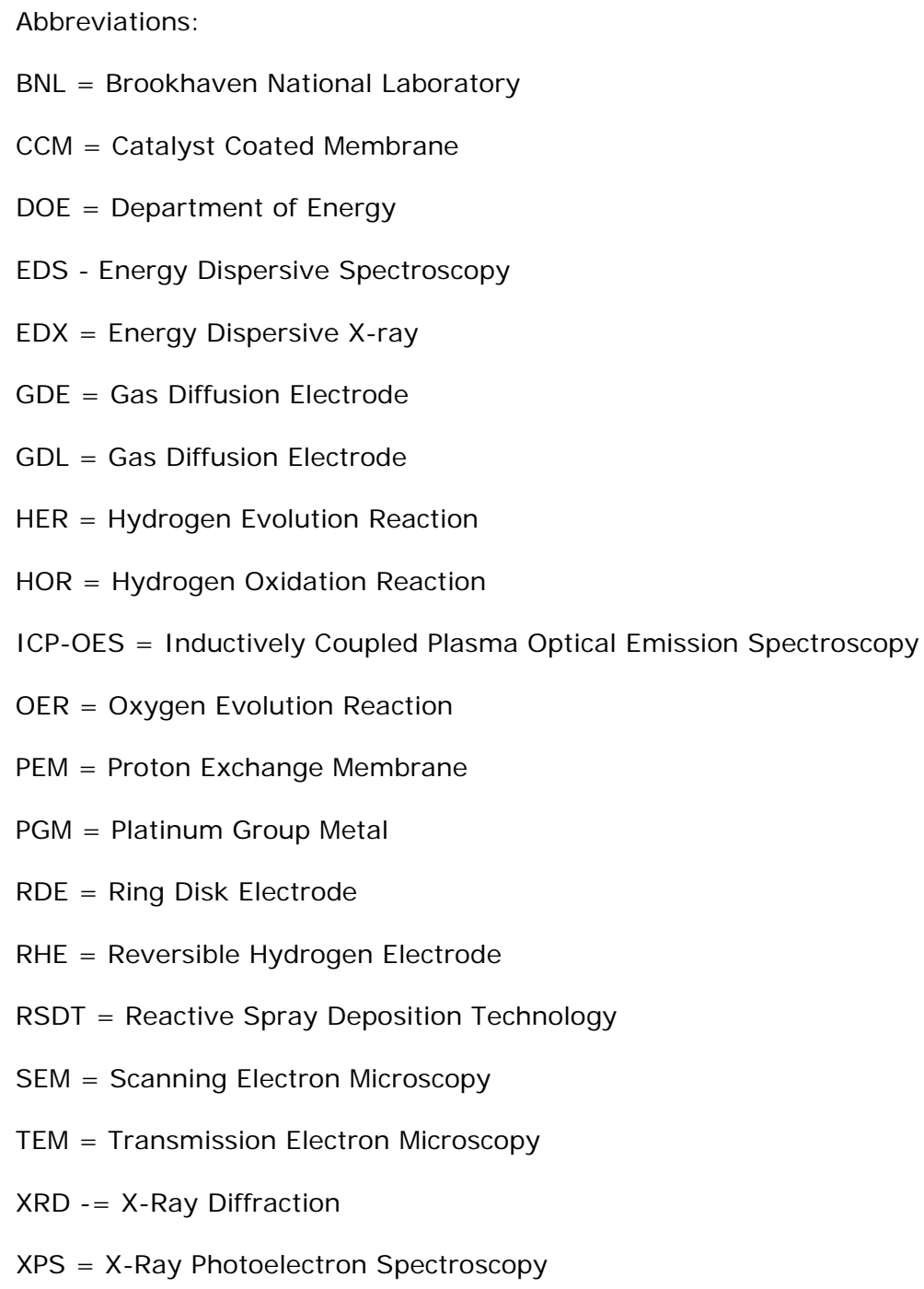


c University of Connecticut, Materials Science and Engineering Department, Chemical and Biomolecular Engineering Department, 191b Auditorium Road, Storrs, CT 06269, USA

‡ Corresponding Author, kayers@protononsite.com

\section{Abstract}

Hydrogen is one of the world's most important chemicals, with global production of about 50 billion $\mathrm{kg} / \mathrm{yr}$. Currently, hydrogen is mainly produced from fossil fuels such as natural gas and coal, producing $\mathrm{CO}_{2}$. Water electrolysis is a promising technology for fossilfree, $\mathrm{CO}_{2}$-free hydrogen production. Proton exchange membrane (PEM)-based water electrolysis also eliminates the need for caustic electrolyte, and has been proven at megawatt scale. However, a major cost driver is the electrode, specifically the cost of electrocatalysts used to improve the reaction efficiency, which are applied at high loadings ( $>3 \mathrm{mg} / \mathrm{cm}^{2}$ total platinum group metal (PGM) content). Core shell catalysts have shown improved activity for hydrogen production, enabling reduced catalyst loadings, while reactive spray deposition techniques (RSDT) have been demonstrated to enable manufacture of catalyst layers more uniformly and with higher repeatability than existing techniques. Core shell catalysts have also been fabricated with RSDT for fuel cell electrodes with good performance. Manufacturing and materials need to go hand in hand in order to successfully fabricate electrodes with ultra-low catalyst loadings $\left(<0.5 \mathrm{mg} / \mathrm{cm}^{2}\right.$ total PGM content) without significant variation in performance. This paper describes the potential for these two technologies to work together to enable low cost PEM electrolysis systems.

\section{Keywords}

electrolysis, catalyst, manufacturing, hydrogen, core shell, platinum 


\section{I ntroduction}

Hydrogen is one of the world's most important chemicals, with global production of about 50 billion kg/yr. Currently, hydrogen is mainly produced from fossil fuels such as natural gas and coal, with $\mathrm{CO}_{2}$ produced as a byproduct. Therefore, there are large environmental impacts possible through development of renewable hydrogen production methods such as electrolysis of water. Energy storage applications in Europe such as wind capture and improved biogas conversion efficiency are also driving significant interest in electrolysis, because penetration of renewable energy is already surpassing acceptable grid levels, and water electrolysis is the only renewable hydrogen technology mature enough to address these needs in the near term. Proton exchange membrane (PEM) electrolysis in particular is attractive due to the dynamic range, reliability, and lack of corrosive electrolyte vs. traditional liquid $\mathrm{KOH}$ electrolyte systems. Figure 1 shows typical operating ranges for liquid $\mathrm{KOH}$ systems vs. commercial PEM systems. In both the $\mathrm{KOH}^{1}$ and Proton case, the polarization curves represent commercial status as of 2012-2014 and do not necessarily represent advancements demonstrated in laboratory stacks. Figure 2 shows reliability data for Proton's cell stacks, demonstrating 60,000 hour lifetimes ( 8 years). The older stack configuration shows a voltage decay rate which would still project to a much longer lifetime, assuming an end of life voltage of $2.6 \mathrm{~V}$, while the newer design shows negligible decay even after 40,000 hours of operation. Liquid $\mathrm{KOH}$ systems have also been claimed to demonstrate similar stack durability. ${ }^{2}$ 


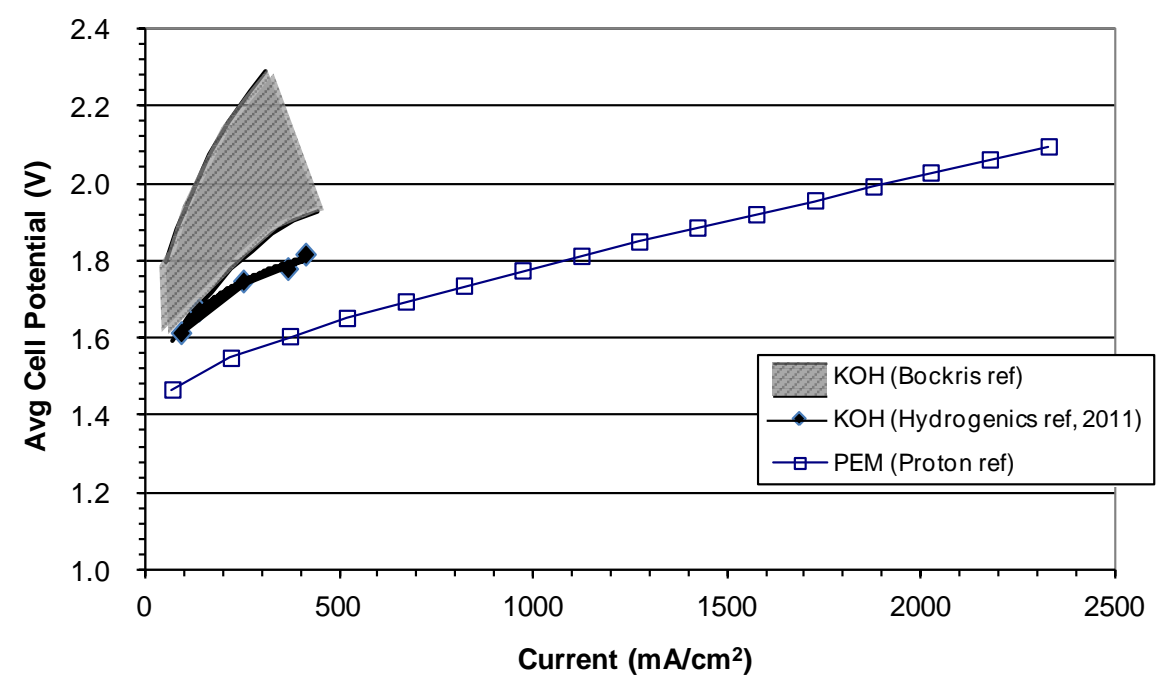

Figure 1: Typical operating ranges for liquid $\mathrm{KOH}^{3}$ and proton exchange membrane electrolyzers. ${ }^{4}$ PEM example is at $50^{\circ} \mathrm{C}$ and uses a 7 -mil Nafion ${ }^{\circledR} \mathrm{N} 117$ membrane, and 7 $\mathrm{mg} / \mathrm{cm}^{2}$ total PGM loading using platinum and $\mathrm{IrO}_{\mathrm{x}}$.

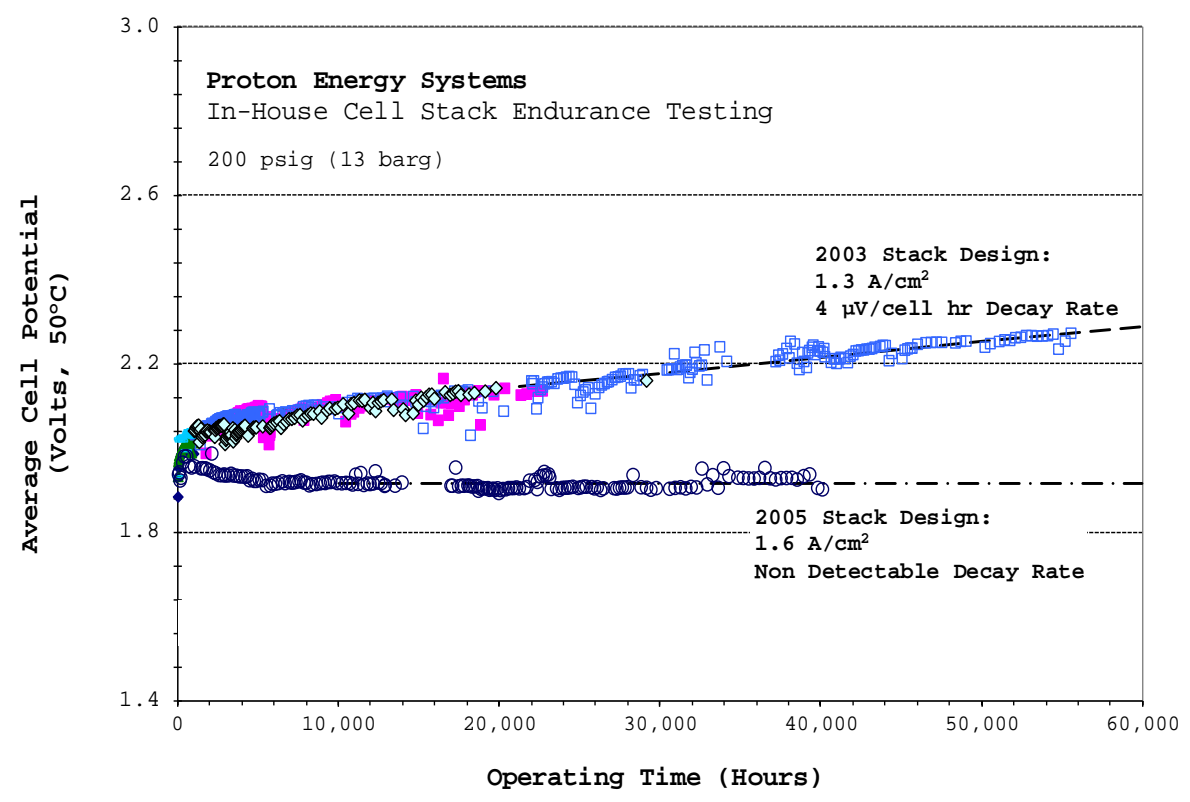

Figure 2: Durability of proton exchange membrane electrolyzers. ${ }^{5}$ Both stacks use 10 -mil Nafion ${ }^{\circledR} \mathrm{N} 1110$ and Pt and $\mathrm{IrO}_{x}$ catalysts at $10 \mathrm{mg} / \mathrm{cm}^{2}$ total PGM loading. 
At smaller scale, the catalyst cost is not a significant cost contribution to the overall system. However, balance of plant cost per output of hydrogen decreases significantly with increases in capacity (Figure 3). This normalized cost drops to less than $30 \%$ of the original cost with a 25 -fold increase in output, and is expected to decrease a similar amount with another order of magnitude increase in power to the 2 MW system. Recently, Proton's DOE funded program to reduce the cost of the bipolar plate resulted in a significant, $40 \%$, cell cost reduction. ${ }^{6}$

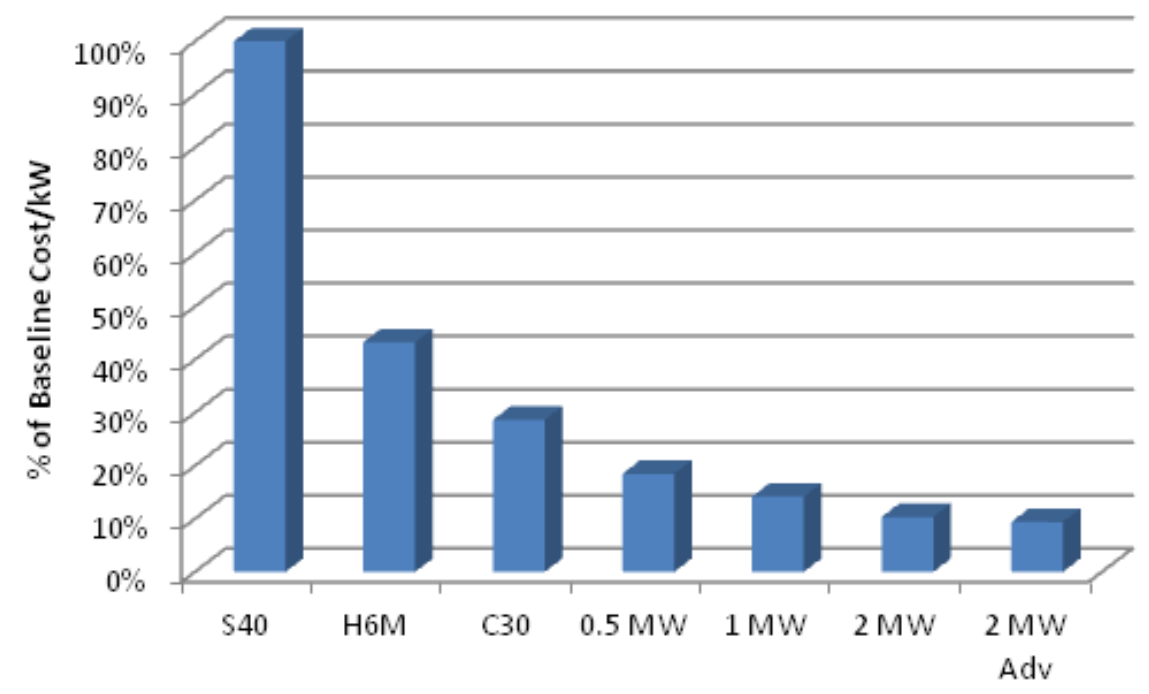

Figure 3: Relative balance of plant cost per kW, normalized to $7 \mathrm{~kW}$ (S40) product

Therefore, a major cost driver at megawatt scale becomes the catalyst coated membrane (CCM). Specifically, the cost of high loadings of platinum group metals and the current labor intensive methods of applying them to the membrane contribute over $30 \%$ of the cell stack cost (Figure 4, left). Proton's megawatt scale product is shown in Figure 4 (right). 

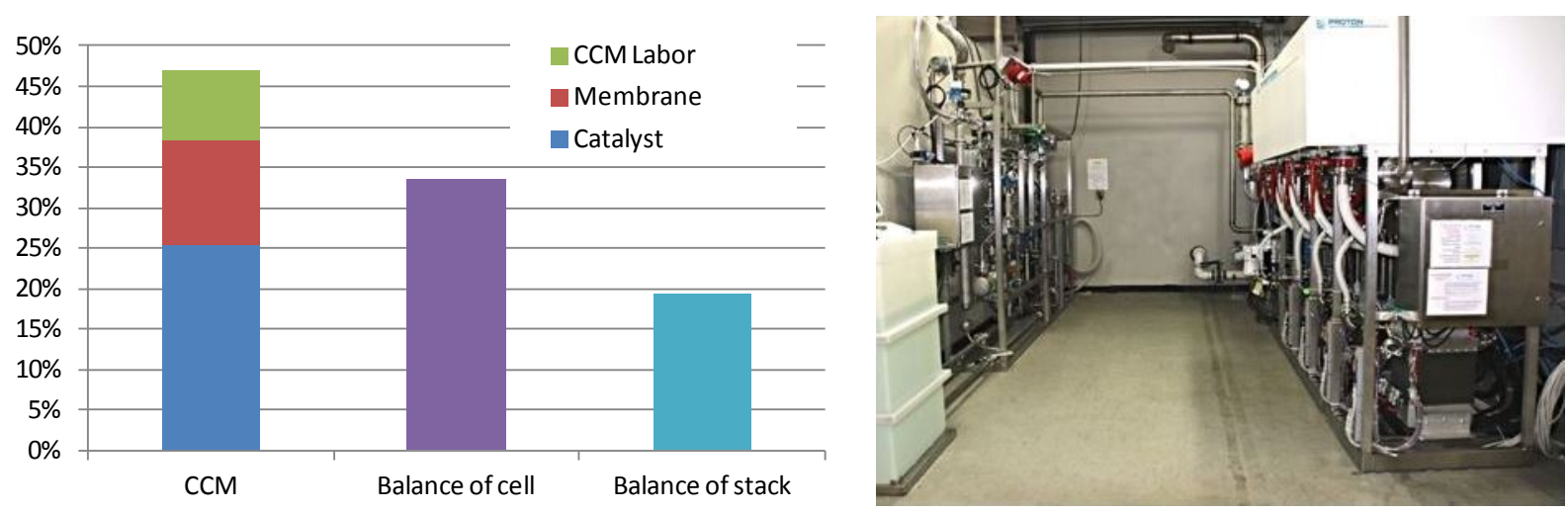

Figure 4: Cost breakdown of stack and photo of Proton MW electrolyzer

Addressing the issue of catalyst cost requires advancements in catalyst activity as well as manufacturing processes. To accomplish this goal, Proton has worked with both Brookhaven National Lab (BNL) as well as University of Connecticut. Brookhaven has developed core shell catalysts which provide high activity at low loading in fuel cells. In collaboration between Proton and BNL, a catalyst composition suitable for the hydrogen evolution was developed that demonstrated high performance and stability concurrent with significant reductions in catalyst loading. In parallel, Proton has been collaborating with the Maric group to develop manufacturing processes for consistent fabrication of low loaded electrodes through directly making and depositing catalyst onto Nafion or gas diffusion layers (GDLs). Core-shell catalyst fabrication with RSDT or any scalable nanomanufacturing process must maintain tight control over shell thickness, down to a monolayer or two, in order to realize the shift in the electronic structure of the shell surface for enhanced catalytic activity. A separate paper focused on RSDT will provide more details on process and theory. Finally, these two advancements can work together to manufacture and deposit core shell materials at low loadings. This paper describes these advancements in core shell catalysts and flame based RSDT techniques as applied separately to PEM electrolysis systems, as well as how these can work together to produce an optimized electrode. 
The concept and practical application of atomic-level core-shell nanocatalysts emerged at beginning of the 21st century. By utilizing Pt spontaneous deposition on metallic Ru nanoparticles, an ultralow-Pt-content catalyst was made with 20:1 Ru: Pt atomic ratio to explore the possibility of placing all the Pt atoms at the surface of Ru particles so that they can be actively involved in hydrogen oxidation reaction and be more tolerant to carbon monoxide impurity due to the influence the Ru core. ${ }^{7,8}$ Only $1 / 8$ monolayer coverage of Pt was deduced based on the particle size and lattice structure observed by high-resolution transmission electron microscopy (TEM). ${ }^{9}$ Encouraged by the performance results, coreshell approach was extended for developing Pt monolayer catalysts for oxygen reduction reaction ${ }^{10}$ using galvanic displacement of an underpotentially deposited $\mathrm{Cu}$ monolayer on $\mathrm{Pd}$ and other metal or alloy cores. ${ }^{11}$ The 1-3 monolayer thick Pt shells on Pd cores were demonstrated using the Z-contrast scanning TEM coupled with element-sensitive electron energy loss spectroscopy when such image technologies just became available in $2008 .{ }^{12}$ Other core-shell-like catalysts for oxygen reduction were formed by the segregation upon annealing of $\mathrm{Pt}_{3} \mathrm{Ni}$ and $\mathrm{Pt}_{3} \mathrm{Co}$ alloys ${ }^{13-15}$ or by de-alloying the non-noble metals in $\mathrm{PtCu}$ and PtCuCo alloys ${ }^{16,17}$ An enhancement in Pt mass activity commonly resulted from increased surface per Pt mass by having other metals in the core and improved catalytic properties of the Pt shell by suitable core metals. The latter is supported by the density functional theory calculations $^{18,19}$ and surface science studies on bulk metals. ${ }^{20}$

The Reactive Spray Deposition Technology (RSDT) is a thin-film deposition process that overcomes many of the shortcomings of traditional vapor deposition techniques while yielding equal or better quality coatings at a lower cost. The RSDT not only provides high quality active films/coatings (e.g., catalysts/electrodes), it also reduces the manpower, energy consumption and number of processing steps required to assemble the films. More specifically, RSDT combines materials synthesis and deposition into a single step with 
several control features, replacing at least 5 unit operations in a conventional electrode manufacturing scheme.

The ability to produce aerosols with narrow size distribution is of critical importance in the RSDT process in which precursor solutions are converted to an ultra-fine mist that is then efficiently combusted to generate nanoparticles. Such ultra-fine, liquid atomization enables using any soluble precursor without concern for its vapor pressure; this essentially represents a paradigm shift in chemical vapor processing. As a production technique it has the potential to inexpensively produce nanopowders as it uses only inexpensive, low vapor pressure precursors. Additionally, only non-toxic and non-halide based chemicals are used making the process is environmentally friendly. Application of the process to deposit catalyst is presented in more detail in other references. ${ }^{21-23}$ In the RSDT process two methods drive the formation of core-shell nanoparticles. One method involves sequential precursor injections with controlled stoichiometry to manufacture the core-shell nanoparticles. A second preferred method involves controlling the solvent chemistry with appropriate reducing agents and additives. This method employs fine temperature and gas phase stoichiometry to encourage sequential nucleation of materials in order to achieve desired core-shell nanoparticle structures.

\section{Material and methods}

2.1 Core shell catalyst fabrication

Fabrication of the Pt/Ru core shell catalysts is described in earlier papers ${ }^{24}$. Briefly, solvent ethanol provides a solution-based reducing environment to fabricate carbon supported Ru nanoparticles and to coat them with Pt atomic layers. To synthesize the Ru particles, an ethanol solution containing carbon powder and $\mathrm{RuCl}_{3}$ is heated, and the color 
of the solution changes from brown to green indicating the reduction of $\mathrm{Ru}^{3+}$ to $\mathrm{Ru}^{2+}$. The reaction is completed by adding alkaline solution. The formation of Ru nanoparticles is initiated by adding aqueous alkaline solution with the molar amount equals to three times of the $\mathrm{RuCl}_{3}$. The supernatant becomes colorless when all the $\mathrm{Ru}$ ions are reduced to metallic particles. The dried Ru particles are subsequently annealed in a furnace purged with hydrogen at $450^{\circ} \mathrm{C}$, resulting in atomic rearrangement to form an ordered structure, and most particles are still below $5 \mathrm{~nm}$ with average sizes of 2 to $3.5 \mathrm{~nm}$ (Figure 5).
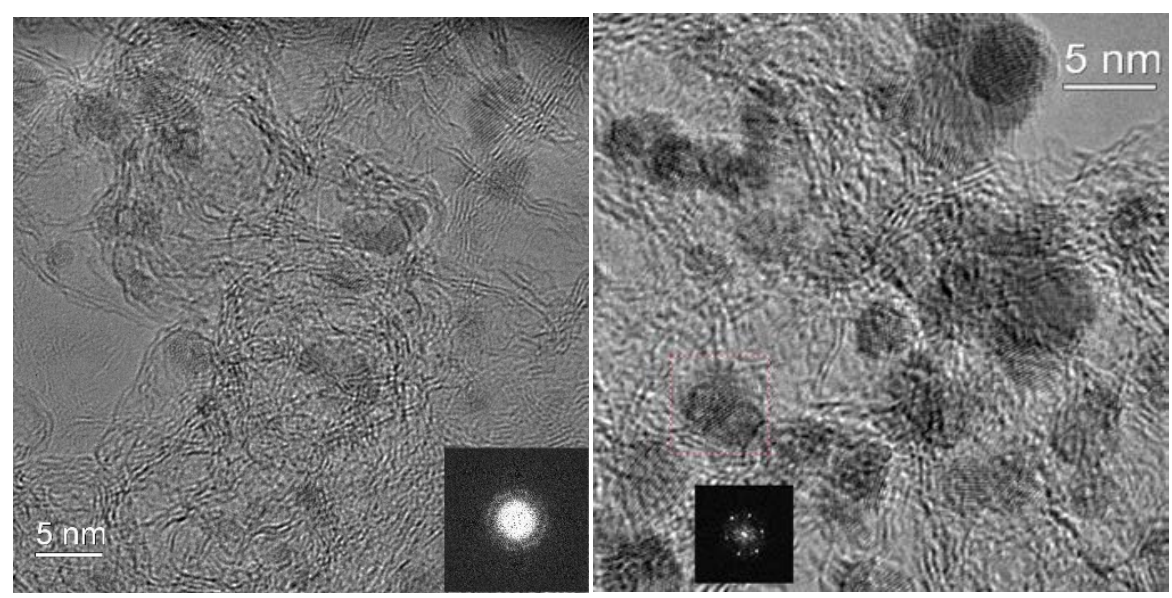

Figure 5: TEM of unannealed (left) and annealed (right) Ru nanoparticles showing the diffused ring diffraction pattern replaced by crystalline material

While not used to fabricate the specific catalysts used here for hydrogen evolution, RSDT has also been shown to result in nanoparticle core-shell formation. Results from UConn's study on RSDT for other Pt based electrocatalysts clearly have shown that the RSDT process allows for depositing two metals by controlling and adjusting liquid precursor vapor pressures or by introducing additives. The gas-phase temperature and composition profiles were explored for slow annealing to favor the thermodynamic intermetallic core particle formation instead of the kinetically favored alloy particles typically formed in rapid gas phase synthesis. Pt shells deposited on $\mathrm{WO}_{3}$ core particles in one processing step is 
presented in Figure 6. Both WO3 precursors and Pt precursors are introduce to the nozzle at the same time.

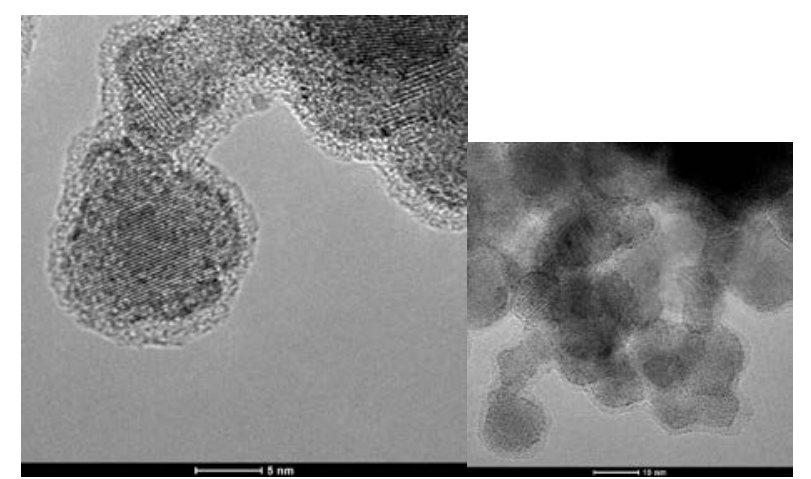

Figure 6: Transmission Electron Microscopy-5 wt\% Pt on WO3. $200 k$ VEI Metrios TEM with an X-FEG source and Super-X EDS

\subsection{Electrode fabrication}

Gas diffusion electrodes were manufactured with the core shell materials by two spray ink techniques. The first was an airbrush technique used for screening. The second leveraged an ultrasonic printer (USI Prism BT Coating System) which could be programmed to apply the desired loading through ink formulation and programming of the nozzle patterns. Catalyst loadings as low as $0.1 \mathrm{mg} / \mathrm{cm}^{2}$ were printed onto several different types of carbon paper, including papers with and without microporous layers (MPLs). Carbon papers used include Sigracet $25 \mathrm{BC}$ as well as Toray TGP-H-090. Proton also developed their own MPL in collaboration with the Paseoguilari group at UConn by using a hydrophilic carbon ink and depositing it on the carbon paper substrate prior to coating with the Ru@Pt nanocatalyst. All baseline materials not specified as Proton commercial parts were airbrushed GDEs. The loading was approximately $3 \mathrm{mg} / \mathrm{cm}^{2}$ of Pt black on Toray or $\mathrm{IrO}_{\mathrm{x}}$ on a porous Ti material for the cathode and anode respectively. 
The RSDT deposition process for the cathode and anode are briefly introduced below. A more detailed description can be found in earlier publications. ${ }^{25-29}$ The RSDT process involves dissolving a metal organic into a combustible solvent. The solution is placed in a sealed container and liquid propane is added from a reservoir to form the final precursor solution. The addition of liquid propane aids in atomization and increases the heat released in the combustion zone. The precursor solution is then pumped using a high-pressure syringe pump into a custom-made atomizing combustor ${ }^{30}$ which consists of three stages: heating, atomizing/mixing, and combustion. The droplet sizes produced by the RSDT nozzle are caused by the simultaneous action of heat, pressure drop, and propane expansion ${ }^{31}$. To ensure complete combustion and limit particle growth during precipitation, the droplets must be confined to $<20 \mu \mathrm{m}$. The droplets are ignited by a ring of pilot burners to form a turbulent jet-diffusion flame. The cathodes were deposited onto N117 membrane with 5*5 $\mathrm{cm}^{2}$ active area (Figure 7). The Pt precursor solution was formulated by adding $5.1 \mathrm{~g}$ of Pt (II) acetylacetonate in to $300 \mathrm{~g}$ of xylene, $100 \mathrm{~g}$ of acetone and $85 \mathrm{~g}$ of liquid propane. The precursor solution was continuously supplied at a constant flow rate of $4 \mathrm{~mL} \mathrm{~min}{ }^{-1}$ through the RSDT nozzle maintained at $190^{\circ} \mathrm{C}$. The oxygen flow was kept at $13.6 \mathrm{~L} \mathrm{~min}^{-1}$. The air

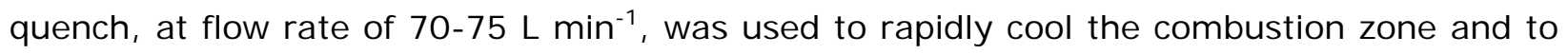
control the particle size as well as maintain the deposition temperature between 100 and $120^{\circ} \mathrm{C}$. The distance between the air quench and the spray injection was kept at $8.9 \mathrm{~cm}$ and the total stand-off distance from the substrate to the spray injection was $19.1 \mathrm{~cm}$. The carbon slurry was prepared by dispersing Vulcan XC-72R in methanol at a concentration of $2.6 \mathrm{mg} \mathrm{mL}^{-1}$ and an ionomer/carbon (I/C) weight ratio of 0.15 . The slurry was sprayed using two 781S-46F air-assisted nozzles (EFD, Inc., East Providence, RI) following the quench, which mounted at $180^{\circ}$ from each other. The flow rate of carbon slurry was 0.75 $\mathrm{mL} \mathrm{min}^{-1}$ per nozzle. 

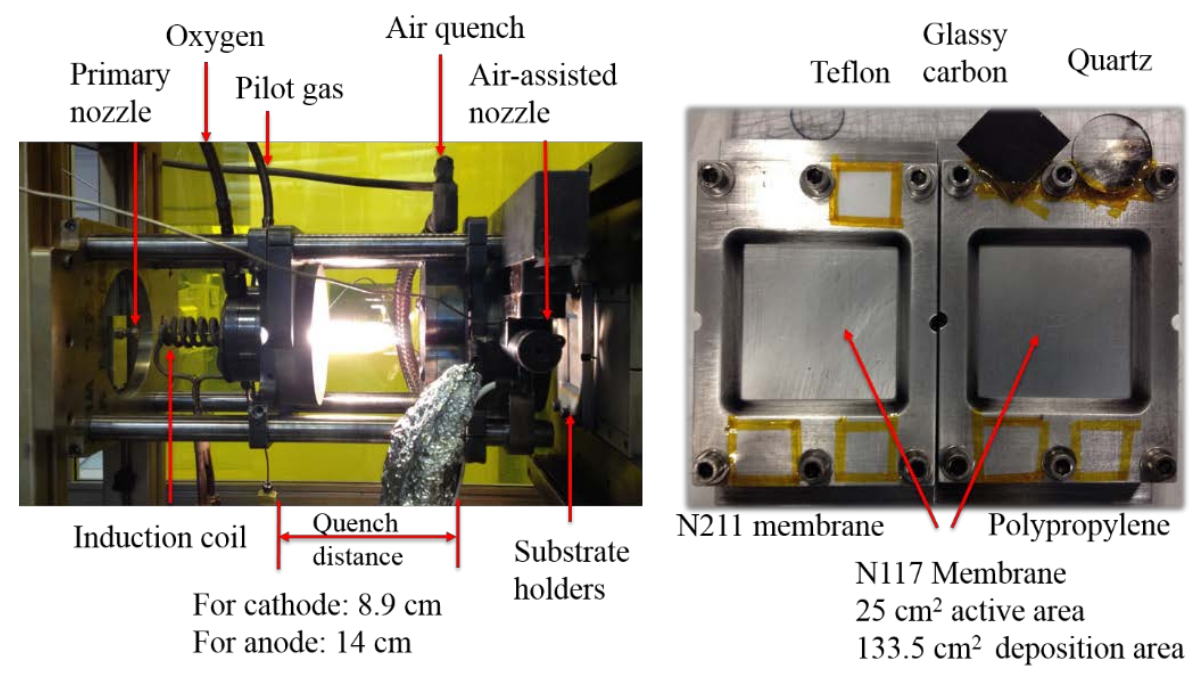

Figure 7. RSDT process view (left) and sample geometry (right).

Similar to the hydrogen electrode, deposition of IrO2 was also explored as a means to directly apply the anode to Nafion $117 \AA$. Ir acetylacetonate (Colonial Metals. Inc) was dissolved in a different combination, a 1:1 vol. ratio of diethylene glycol monobutyl-ether (Fisher Scientific), and ethanol (Fisher Scientific, Absolute 200 Proof) at 5-10 mM L-1. Liquid propane were added to Ir precursor solutions with 15 wt.\% prior to deposition to aid atomization and increase the combustion heat in RSDT process. $1 \mathrm{rO}_{2}$ is deposited as a highly branched (agglomerated) structure and is was fully crystalline.

For anode fabrication, the Ir precursor solution was formulated by adding $2.44 \mathrm{~g} \mathrm{of} \mathrm{Ir}$ (III) acetylacetonate into $237.5 \mathrm{~g}(250 \mathrm{~mL})$ of diethylene glycol mono-butyl ether, $197 \mathrm{~g}$ ( $250 \mathrm{~mL}$ ) of ethanol and $85 \mathrm{~g}$ of liquid propane. The precursor solution was supplied to the

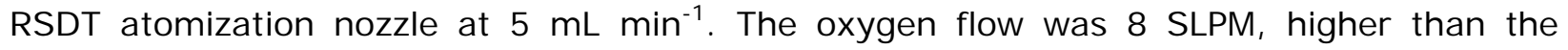
stoichiometric flow at 6.5 SLPM. The distance between the air quench and the spray injection was increased to $14 \mathrm{~cm}$ in order to obtain an elongated hot zone of combustion and particle growth. The air quench flow rate was adjusted at $55 \mathrm{~L} \mathrm{~min}^{-1}$ to maintain the substrate temperature at $110 \pm 10^{\circ} \mathrm{C}$. Diluted Teflon solution $(0.05$ wt $\%$ in DI water) was sprayed following the air quench in the same manner as the spray of carbon slurry. For 
supported ITO anode, the ITO slurry was sprayed at $0.875 \mathrm{~mL} \mathrm{~min}^{-1}$ per nozzle. ITO was synthesized in the Mustain lab at UConn per a previously published procedure. ${ }^{32}$ Other RSDT parameters were the same as the cathode fabrication except that pure xylene was sprayed for flame combustion.

Throughout this study, the RSDT method was used to deposit either 2 or 3 identical samples at once, in addition to the catalyst layers deposited on other substrates within the same experiment for easier physical characterization. The sample holder was designed to hold these multiple substrates and the spray was programmed to cover the entire sample holder area, with the appropriate areas masked (Figure 7). This approach allows some testing of duplicate samples, or testing of one sample in the screening cell followed by testing of the duplicate electrode in the $28 \mathrm{~cm}^{2}$ pressurized cell.

\subsection{RSDT catalyst layer physical characterization}

X-ray diffraction patterns (XRD) of as-deposited CLs on quartz were obtained with 0.02 degree step size and 5 s per step on Bruker D8 Advance diffractometer, configured with a $\mathrm{Cu} \mathrm{K}_{\mathrm{a}}(1.541 \AA$ ) source, a $\varnothing 250 \mathrm{~mm}$ goniometer in Bragg-Brentano geometry, and a compound silicon strip 1-dimensional LynxEye detector. The surface morphology and electrode thickness were characterized by FEI Quanta FEG 250 scanning electron microscopy (SEM) with a field emission source and Everhart-Thornley (secondary electron) detector. The surface elemental distribution was explored by Energy Dispersive X-ray (EDX) spectroscopy under the Genesis Apex System from EDAX, AMETEK, Inc. Micrographs of transmission electron microscopy (TEM) were obtained by FEI Tecnai T12 with a LaB $_{6}$ source at $120 \mathrm{keV}$. Bulk elemental analysis of the deposited films was determined by inductively coupled plasma optical emission spectroscopy (ICP-OES) using a Perkin Elmer Optima 7300DV ICP-OES. X-ray photoelectron spectroscopy (XPS) was performed using a 
Physical Electronics multiprobe with a Perkin-Elmer dual anode X-ray source and a Kratos AXIS-165 surface analysis system to examine the surface composition.

The electrochemical measurements were conducted on a typical three-compartment electrochemical cell equilibrated at $25^{\circ} \mathrm{C}$. The potential was determined using $\mathrm{Hg} / \mathrm{HgSO}_{4}$ reference electrode with a potential of $0.72 \mathrm{~V}$ vs. RHE. A Pt flag was used as the counter electrode. An AutoLab PGSTST302N potentiostat was used for all measurements. The working electrode was formed by direct deposition of IrOx on Au disk ( $5 \mathrm{~mm}$ diameter). Prior to the measurement, the working electrode underwent electrochemical cleaning by cycling between $0.0 \mathrm{~V}$ and $1.4 \mathrm{~V}$ (vs. RHE) at a scan rate of $200 \mathrm{mV} \mathrm{s}^{-1}$ for 40 cycles. Then, cyclic voltammogram (CV) was collected in nitrogen-purged cell between 0.0V and 1.4V (vs. RHE) at a scan rate of $20 \mathrm{mV} \mathrm{s}^{-1}$ for 30 cycles. The polarization curves for oxygen evolution reaction (OER) was recorded at a scan rate of $5 \mathrm{mV} \mathrm{s}^{-1}$ from 1.2 to $1.8 \mathrm{~V}$ with a rotation speed of $1600 \mathrm{rpm}$. All potentials were reported relative to reversible hydrogen electrode (RHE).

2.5 Cell assembly and test

For initial testing of both printed Brookhaven catalysts and RSDT sprayed electrodes, a $25 \mathrm{~cm}^{2}$ fuel cell from Fuel Cell Technologies was modified for electrolysis testing. The carbon flow field on the oxygen side of the cell was replaced with a titanium plate with parallel channels, and a titanium gas diffusion layer was used. Either a catalyst coated membrane was fabricated through RSDT, or a gas diffusion electrode was printed with a spray coater or through RSDT. The $25 \mathrm{~cm}^{2}$ cell was assembled including the endplates, flow fields, gas diffusion layers, membranes and gaskets. The membrane used was Nafion ${ }^{\circledR} 117$ in all cases. Cells were allowed to hydrate at elevated temperature (typically $80^{\circ} \mathrm{C}$ ) and under pressure on the endplates overnight in order to allow the electrodes to bond well 
between the GDL and the membrane. In this cell, polarization curves were collected by holding the current for 5 minutes at each step. Limited durability testing was performed by holding the current at $1.8 \mathrm{~A} / \mathrm{cm}^{2}$ for several hours and collecting data. Temperature was controlled to $50^{\circ}$ or $80^{\circ} \mathrm{C}$. This system is not set up for unattended operation overnight. The system consists of Teflon coated subversive heaters and thermal controllers regulate the DI water temperature. The water is circulated via diaphragm pump capable of supplying 300 $\mathrm{mL} / \mathrm{min}$. In-line water polishing through a mixed de-ionizing bed was performed. During operation the hydrogen was vented to a chemical safety hood.

Downselected configurations were similarly inserted into Proton's commercial $28 \mathrm{~cm}^{2}$ electrolysis cell stack, both to verify the $25 \mathrm{~cm}^{2}$ cell performance as well as to test durability and performance in the most relevant environment. This stack and the associated test stands are rated for overnight operation, and typically operate at 435 psi hydrogen pressure, with ambient oxygen pressure. These test stands are similar in function to the 25 $\mathrm{cm}^{2}$ test stand described above but are more robust, with regulators to safely operate at differential pressure and the use Citect software to control temperature, voltage and data collection. After the hydration/bonding step, polarization curves were also taken in this cell configuration, then the stack was allowed to operate at $1.8 \mathrm{~A} / \mathrm{cm}^{2}$ for up to 500 hours at $50^{\circ}$ or $80^{\circ} \mathrm{C}$ and 435 psi differential pressure.

\section{Results}

3.1 Core shell catalyst technology transfer and scale up

A total of five nanoparticle synthesis trials were performed at Proton to replicate the synthesis process developed at BNL. (Table 1 ). The first three trials were not successful in producing desired Ru nanoparticles. Consultation with BNL provided a number of 
specifications to judge the quality of the process, including the change of solution color before adding carbon power (Figure 8), the right amount of alkaline solution used in trigging and completing the reactions, and the final product weight being consistent with that calculated from the metal precursors and carbon powders. After the audit, all targets were met. This indicated that Proton had transferred the synthesis process from BNL, and can perform it reproducibly in-house.

Table 1: Proton synthesis trials of Ru@Pt nanocatalysts showing on-target specifications (green) and off-target specifications (red).

\begin{tabular}{|c|c|c|c|c|c|}
\hline & \multicolumn{5}{|c|}{ Synthesis Targets: } \\
\hline $\begin{array}{c}\text { Synthesis } \\
\text { Trial }\end{array}$ & $\begin{array}{c}\text { Color Change } \\
\text { (green) }\end{array}$ & $\begin{array}{l}\text { Ru soln. } \\
\mathrm{pH}(5-7)\end{array}$ & $\begin{array}{l}\text { Weight (within } \\
\pm 5 \% \text { of target) }\end{array}$ & $\begin{array}{l}\text { Pt soln. } \mathrm{pH} \\
(<1)\end{array}$ & $\begin{array}{l}\text { Final Weight (within } \\
\qquad \pm 5 \% \text { of target) }\end{array}$ \\
\hline 1 & green & 10 & $200 \%$ & $\begin{array}{l}\text { synthesis } \\
\text { terminated }\end{array}$ & $\begin{array}{l}\text { synthesis } \\
\text { terminated }\end{array}$ \\
\hline 2 & green & 9 & $-20 \%$ & $\begin{array}{l}\text { synthesis } \\
\text { terminated }\end{array}$ & $\begin{array}{l}\text { synthesis } \\
\text { terminated }\end{array}$ \\
\hline 3 & green & 8 & $-20 \%$ & $\begin{array}{l}\text { synthesis } \\
\text { terminated }\end{array}$ & $\begin{array}{l}\text { synthesis } \\
\text { terminated }\end{array}$ \\
\hline 4 & green & 5 & $2.00 \%$ & 0.3 & $0.2 \%$ \\
\hline 5 & green & 5 & $-0.10 \%$ & 0.4 & $3 \%$ \\
\hline
\end{tabular}

Proton then scaled the synthesis process by a factor of 10. An example of the relative amounts of reactants is described here based on $3.9 \mathrm{~g}$ of $\mathrm{RuCl}_{3}$ precursor as a starting point. The RuCl3 and 5 liters of ethanol are added to a beaker. The solution is transferred into a $10 \mathrm{~L}$ round bottom flask and stirred while the oil bath is kept at $110^{\circ} \mathrm{C}$ for one hour. Five grams of Ketjen Black carbon powder is then added in $500 \mathrm{~mL}$ of ethanol with high 
stirring, followed by dropwise addition of $\mathrm{NaOH}$. After 2 hours of stirring, the $\mathrm{pH}$ is further adjusted and the solution is cooled and filtered.

When Proton synthesized the larger batch, it required separation into 3 batches in order to eliminate self-ignition on drying. The powder was then annealed. In the second step, 6 $\mathrm{g}$ of $\mathrm{Ru} / \mathrm{C}$ was sonicated in $2500 \mathrm{~mL}$ ethanol at $110^{\circ} \mathrm{C}$. The solution was cooled to $45^{\circ} \mathrm{C}$ and $400 \mathrm{~mL}$ of $0.05 \mathrm{M} \mathrm{H}_{2} \mathrm{PtCl}_{6} \cdot 6 \mathrm{H}_{2} \mathrm{O}$ in ethanol was added. This solution was stirred for 2 hours at $80^{\circ} \mathrm{C}$. $200 \mathrm{~mL}$ of $0.2 \mathrm{M} \mathrm{NaOH}$ was then added and the solution was cooled to room temperature. The powder was rinsed with ethanol and then water to remove residuals. The catalyst was then dried under nitrogen. The catalysts' performance was verified to be comparable to those made in small batches by hanging-strip GDE tests performed at BNL. We then used the Ru@Pt core-shell catalysts for the remainder of the project.
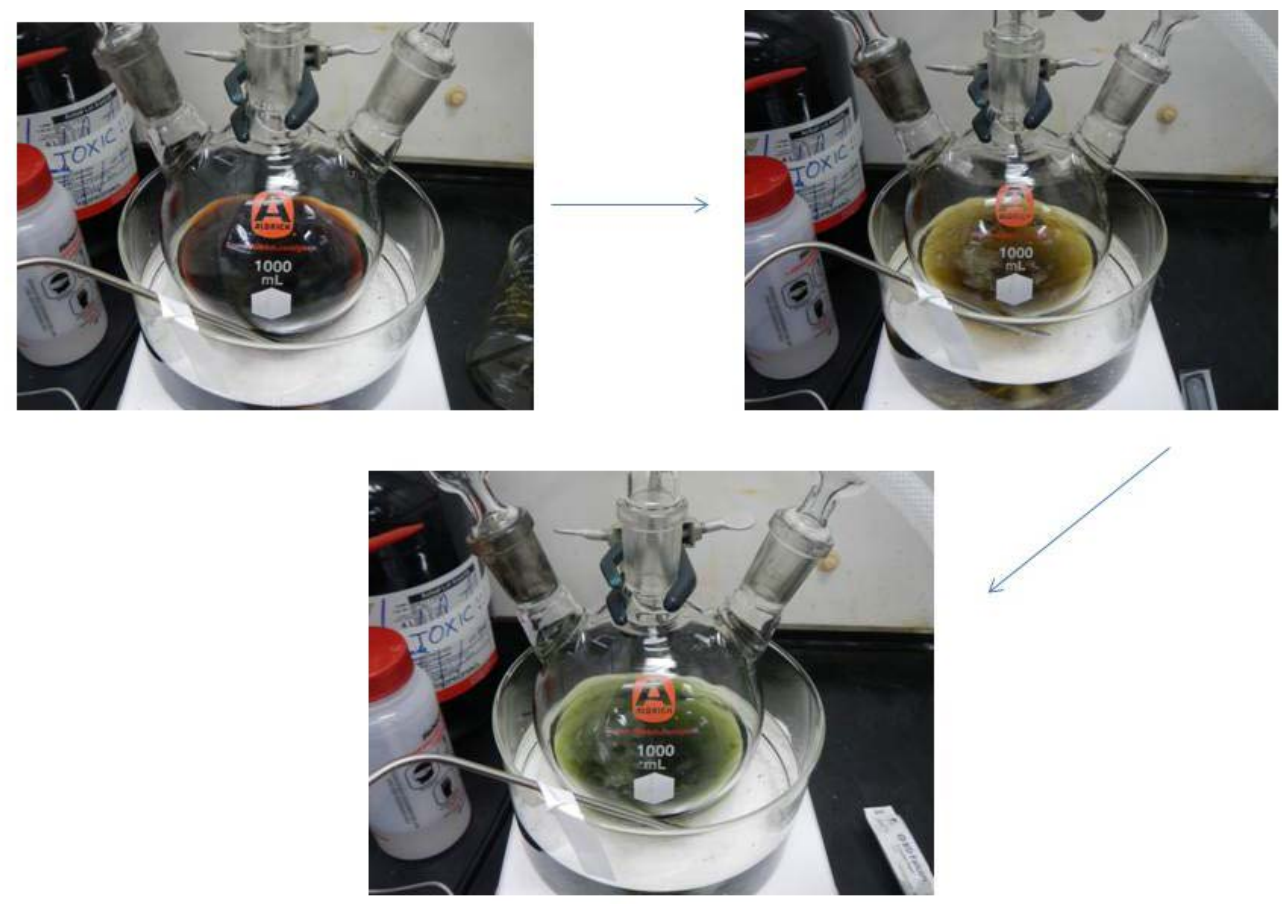

Figure 8: Color transformation of ruthenium solution from dark brown to green.

\subsection{Cell testing of low loaded core shell catalysts}


The scaled up material was tested in Proton's $25 \mathrm{~cm}^{2}$ bench-scale electrolyzer and compared to a baseline gas diffusion electrode. The cathode with the core shell catalyst was typically made with $0.1-0.3 \mathrm{mg} / \mathrm{cm}^{2}$ loadings roughly $1 / 10^{\text {th }}$ the PGM loading (including $\mathrm{Ru}$ ) compared to the baseline. Polarization data was obtained, showing the scaled-up material has equivalent performance to baseline (Figure 9).

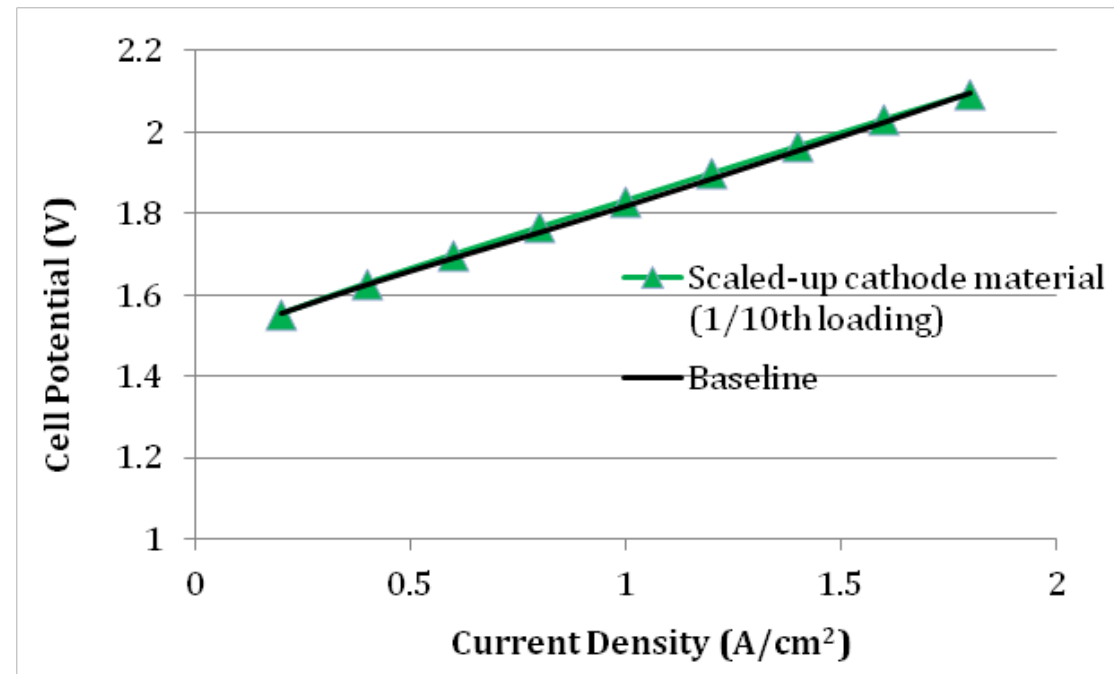

Figure 9: Equivalent performance for core shell material vs. baseline. Both tests were conducted with Nafion ${ }^{\circledR} \mathrm{N} 117$ membrane at $50^{\circ} \mathrm{C}$ and with baseline counter GDE anodes which had a loading of approximately $3 \mathrm{mg} / \mathrm{cm}^{2}$ of the same $\mathrm{IrO}_{\mathrm{x}}$ material.

A loading study was also performed for the baseline catalyst vs. the core shell material. As seen in Figure 10, reducing the loading to $10 \%$ of baseline with traditional catalyst powders resulted in significant performance loss. The core shell material is therefore required to maintain the high activity at lower loading. Larger electrodes have also been made and tested with similar results. 


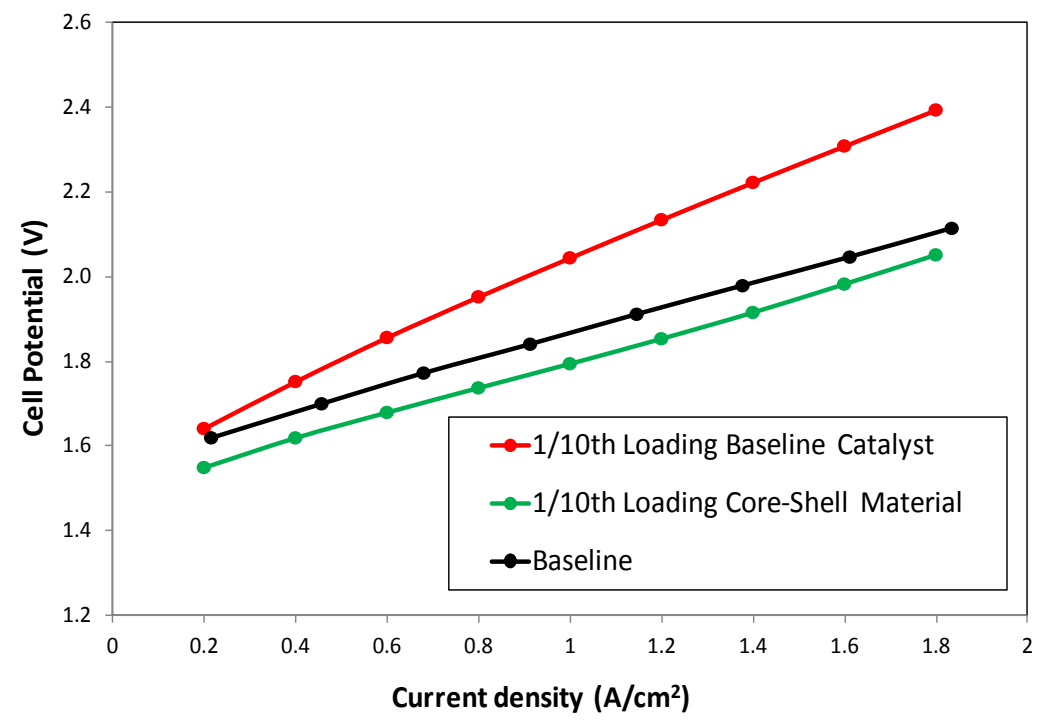

Figure 10: Traditional catalyst at low loading vs. core shell. All tests were conducted with Nafion ${ }^{\circledR} \mathrm{N} 117$ membrane at $50^{\circ} \mathrm{C}$ and with baseline counter GDE anodes which had a loading of approximately $3 \mathrm{mg} / \mathrm{cm}^{2}$ of the same $\mathrm{IrO}_{\mathrm{x}}$ material.

\subsection{RSDT electrode characterization}

The Pt/C cathodes were fabricated with $0.3 \mathrm{mg} \mathrm{cm}^{-2}$ and $0.1 \mathrm{mg} \mathrm{cm}^{-2}$ loading and the electrode thickness was ranged from 14 to $17 \mu \mathrm{m}$ and 11 to $15 \mu \mathrm{m}$, respectively. (Figure 11 a, c) Both samples showed comparable thickness and good catalyst layer adhesion on the membrane pre- and post-CCM testing (Figure 11 a-d), indicating good integrity of electrode materials during electrolysis operation. The core-shell structure RSDT process is under evaluation and will be published in a separate paper. The $\mathrm{IrO}_{\mathrm{x}}$ anode had an $\mathrm{Ir}$ loading of $0.1 \mathrm{mg} \mathrm{cm}^{-2}$. The surface morphology was characterized by spherical I $\mathrm{rO}_{\mathrm{x}}$ agglomerates and high roughness (Figure 12a, b). The catalyst layer had a thickness ranged from 2 to $3 \mu \mathrm{m}$ (Figure 12c). From the cross-section image we observed that mesopores were formed through the packing of spherical IrOx agglomerates (Figure 12d), which is considered to be advantageous for water and gas transport during the water electrolysis operation. Work is ongoing to measure the electrochemically active surface area (ECSA) of these materials, 
particularly the IrOx samples. Iridium is more difficult to measure than platinum since it does not have the ability to underpotential adsorb protons. The Mustain group at UConn has been developing new techniques for measuring ECSA of iridium oxide, and has written a separate paper which will be published. ${ }^{33}$
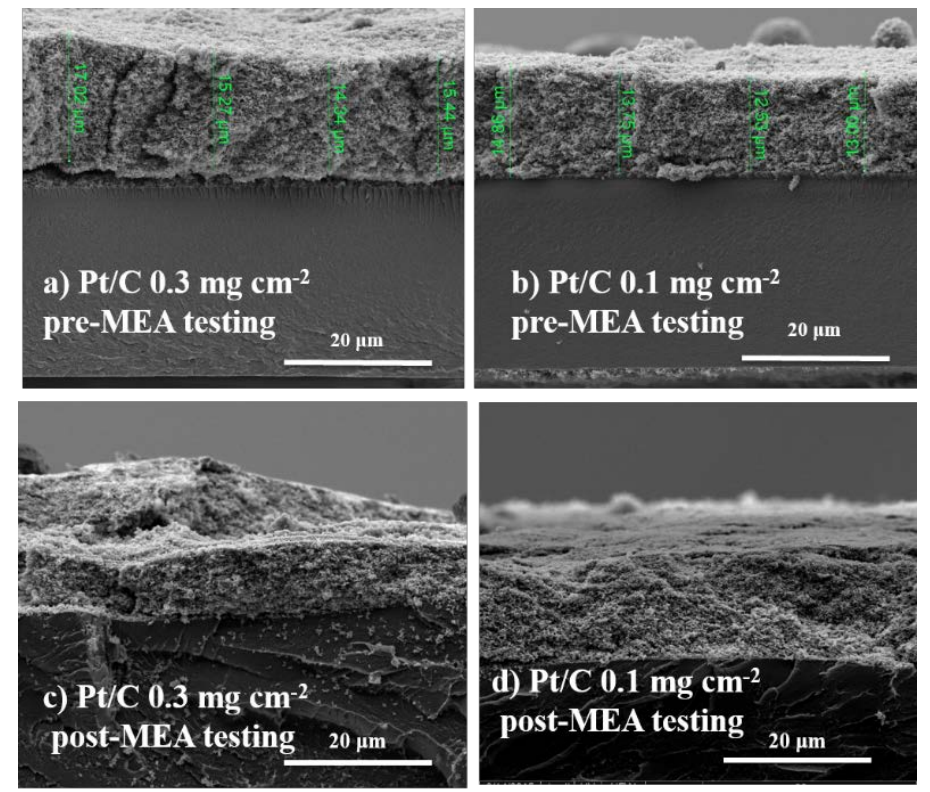

Figure 11. Catalyst layer cross-section images of Pt/C cathode pre- and post-CCM testing 

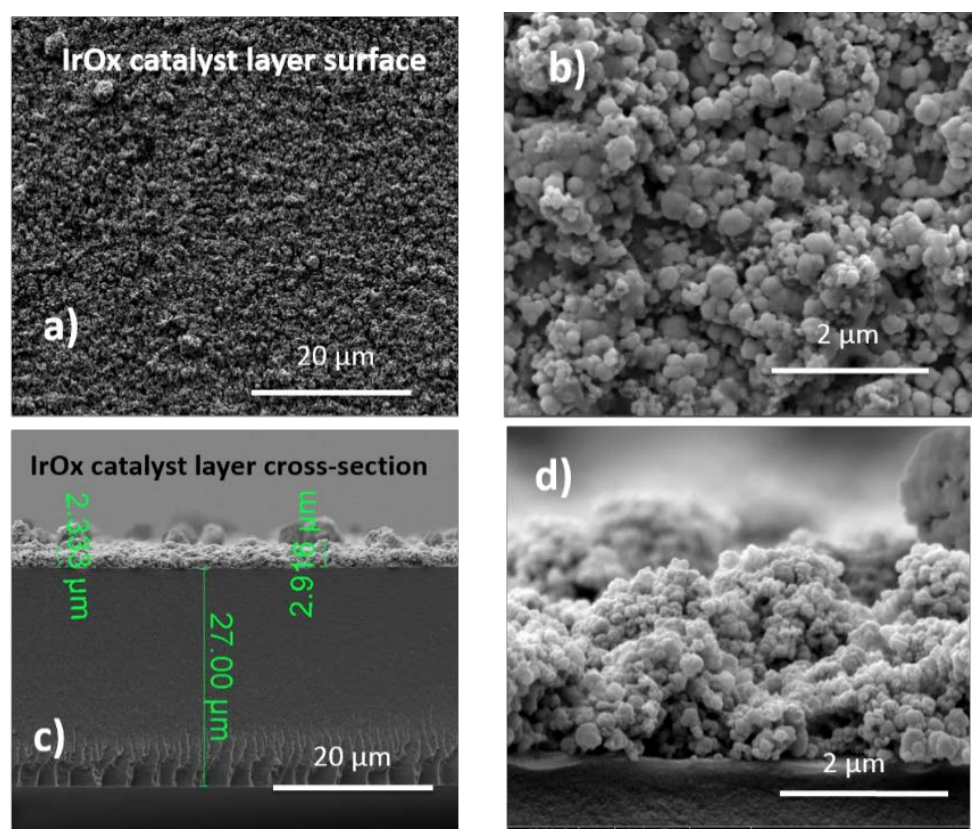

Figure 12. Surface morphology (a, b) and cross-section (c, d) of I rOx anode catalyst layer

For TEM analysis of IrOx particles, two methods were used to fabricate the TEM specimen. The first method was to directly collect the IrOx particle at the same stand-off distance for CCM deposition. The carbon TEM grids were exposed to the flame for 45s (Figure 13a,b). The individual I rOx particles had an average size of $2.0 \mathrm{~nm}$ (Figure 13b) and the majority of the particles lies in the range of 1.5 to $2 \mathrm{~nm}$. To characterize the IrOx agglomerate by TEM, the as-deposited IrOx thin film was scraped off from the Teflon coupon (Figure 7) and dispersed in ethanol. A few drops of dispersion was placed on the TEM grid and dried. The scraped off IrOx was agglomerated by small I rOx particles (Figure $13 c, d)$ that approximately had the same size as shown in Figure $13 a$ and b. 

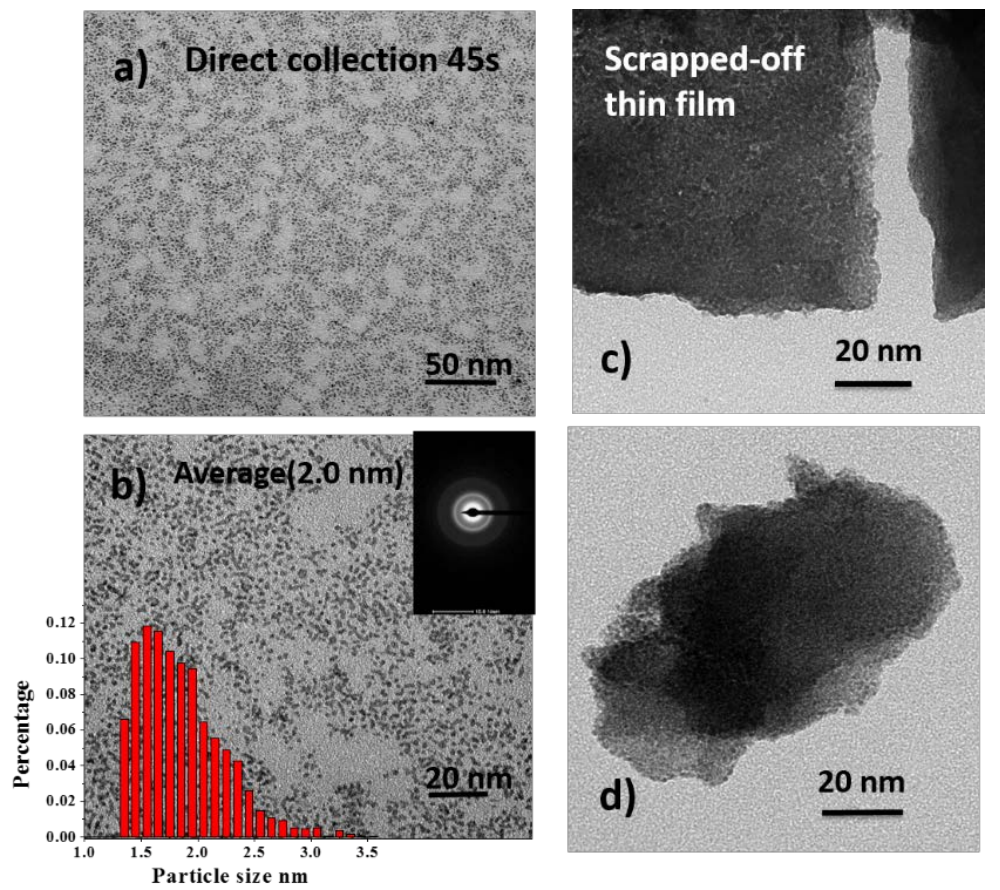

Figure 13. TEM micrographs of IrOx particles $(a, b)$ and IrOx agglomerates $(c, d)$.

To estimate the intrinsic OER activity of RSDT-derived IrOx catalyst, electrochemical measurements using rotating disk electrode (RDE) were conducted on an Au disk directly deposited by IrOx. The estimated IrOx loading was $60 \mu \mathrm{g} \mathrm{cm}^{-2}$. The cyclic voltammogram (Figure 14a) shows typical Ir (III/IV) redox couple between 0.9 and $1.0 \mathrm{~V}$ (Vs. RHE). ${ }^{34}$ We compared the mass activity of $\mathrm{Ir}_{0.59} \mathrm{Ru}_{0.41} \mathrm{O}_{2-y}$ catalyst reported previously with I rOx shown in Figure 14c. The OER onset potential for I rOx was delayed by $\sim 50 \mathrm{mV}$ comparing to $\mathrm{Ir}_{0.59}$ $\mathrm{Ru}_{0.41} \mathrm{O}_{2-\mathrm{y}}$. 

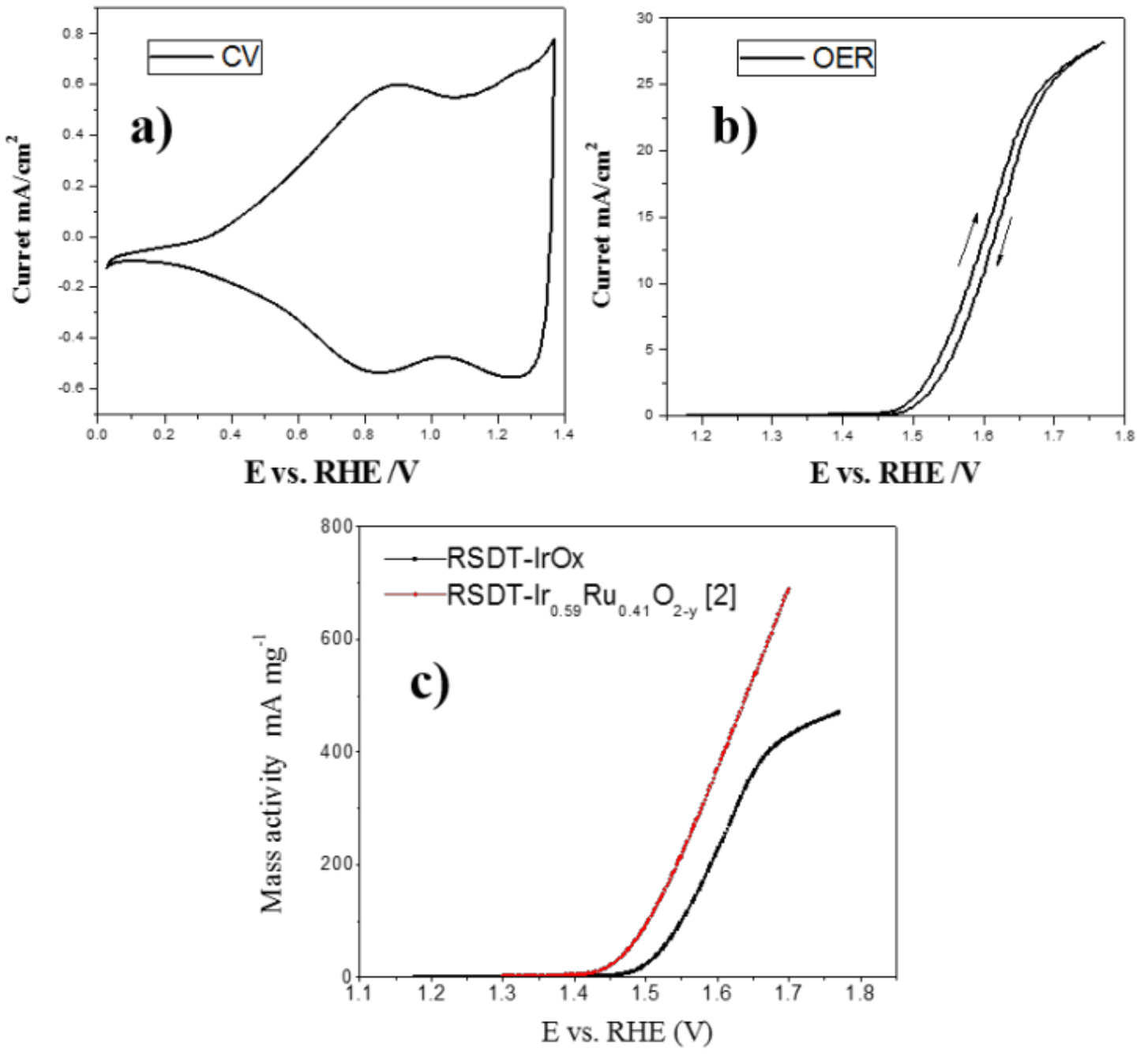

Figure 14. Cyclic voltammetry (a) and oxygen evolution reaction (b) behavior of RSDTderived IrOx thin film on Au disk electrode. Scan rate CV: $20 \mathrm{mV} \mathrm{s}^{-1}$; OER: $5 \mathrm{mV} \mathrm{s} \mathrm{s}^{-1} .25^{\circ} \mathrm{C}$, $0.5 \mathrm{M} \mathrm{H}_{2} \mathrm{SO}_{4}$. (c) Compares the mass activity with $\mathrm{Ir}_{0.59} \mathrm{Ru}_{0.41} \mathrm{O}_{2-y}$ catalyst reported in ref 25 through RSDT deposition.

MEA data for the anodes prepared by RSDT under different configurations are presented in Figure 15. The highest performing anode in Fig. 15. has $0.1 \mathrm{mg} \cdot \mathrm{cm}-2$ of $\mathrm{IrO}_{\mathrm{x}}$ loading with Nafion 117 and was evaluated at $50^{\circ} \mathrm{C}$ under ambient pressure. The Nafion to $\mathrm{IrO}_{\mathrm{x}}$ ratio was 0.1 . 


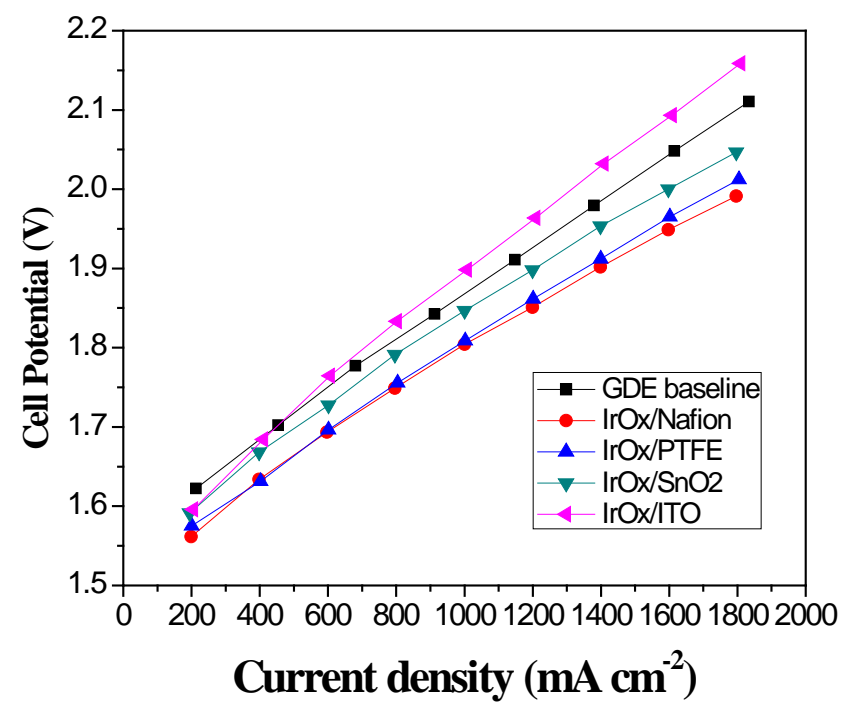

Figure 15. MEA of IrOx based anodes deposited by RSDT process.

Figure 16 compares the mass activity for the RSDT generated anodes vs. other literature results. This is one the best performing low PGM loaded anode catalyst reported to date. ${ }^{35-}$ 38 The durability of this anode is under evaluation and $300 \mathrm{~h}$ of stable performance has been measured.

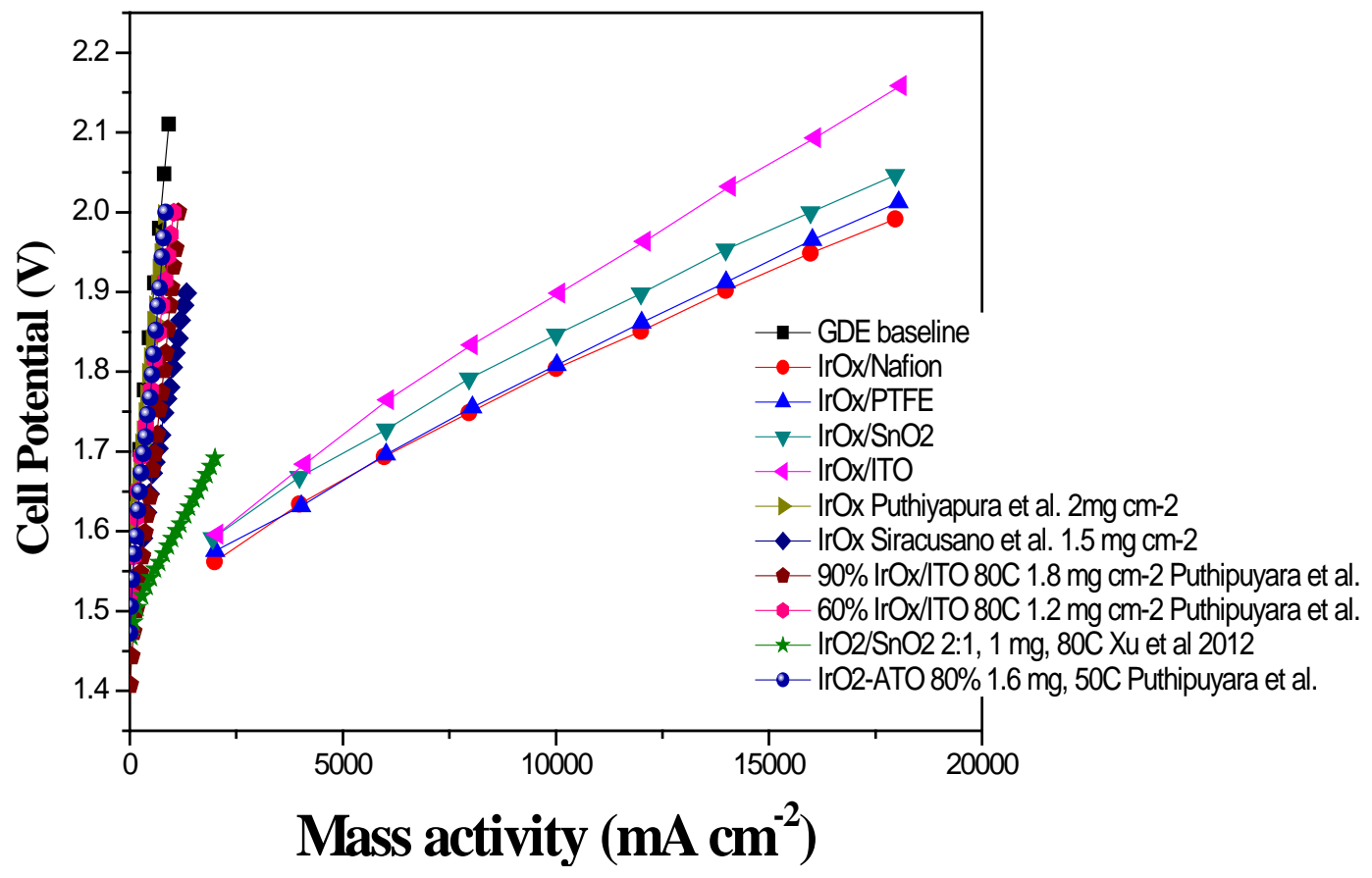

Figure 16: Mass activity of IrOx anodes under different deposition conditions 


\subsection{Cell testing of RSDT deposited electrodes}

For the cathode, RSDT coatings were tested both as catalyst coated membrane (CCM) or gas diffusion electrode (GDE) configurations. For comparison, Brookhaven core shell catalysts have only been tested at GDEs to date at Proton. To test the UConn deposited electrodes, the corresponding baseline GDE counter electrode was used in all cases. Figure 17 (left) shows the polarization data for the bench test $25 \mathrm{~cm}^{2}$ cell, demonstrating equivalent performance for the catalyst coated membrane sample, and an extra resistance component in the gas diffusion electrode. However, both samples do not show mass transport limitations even at these low catalyst loadings. While the GDE results are expected to also improve with further study, the CCM configuration was translated to Proton's commercial $28 \mathrm{~cm}^{2}$ hardware as the more promising early pathway. Figure 17 (right) shows the steady state performance for a cell operated at $2 \mathrm{~A} / \mathrm{cm}^{2}, 50^{\circ} \mathrm{C}$. Cell optimization still needs to be performed to ensure proper contact across the surface of the RSDT electrode in the $28 \mathrm{~cm}^{2}$ cell, which should improve the voltage, but the performance was stable over time.
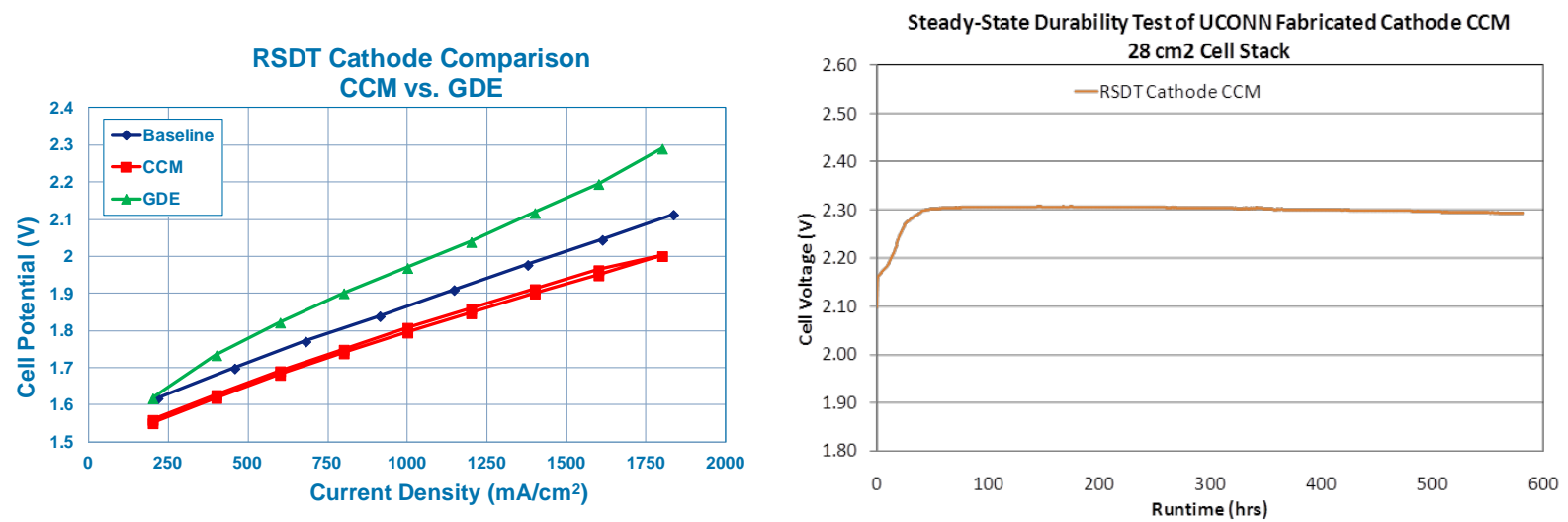

Figure 17: Polarization data and steady state operation for 500 hours. Tests were conducted with Nafion ${ }^{\circledR} \mathrm{N} 117$ membrane at $50^{\circ} \mathrm{C}$ and with baseline counter GDE anodes which had a loading of approximately $3 \mathrm{mg} / \mathrm{cm}^{2}$ of the same $\mathrm{IrO}_{\mathrm{x}}$ material. 
For the anode, RSDT electrodes were fabricated using either the in situ formed iridium oxide as described in Section 2.4, or iridium oxide nanopowder catalyst was dispersed in solution and deposited using the same conditions. These electrodes were tested in the $25 \mathrm{~cm}^{2}$ cell at $50^{\circ} \mathrm{C}$, with results in Figure 18 . The RSDT in-situ formed catalyst performed better than the dispersed catalyst as an initial run, and continues to be evaluated for durability.

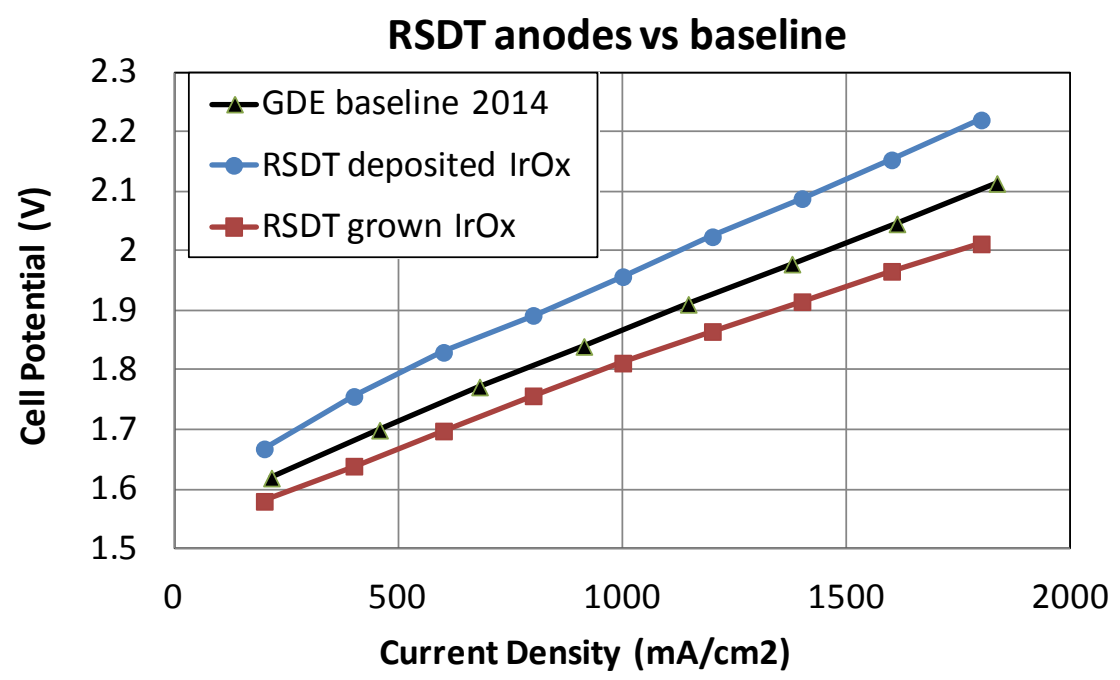

Figure 18: Comparison of RSDT anodes vs. baseline. Tests were conducted with Nafion ${ }^{\circledR}$ $\mathrm{N} 117$ membrane at $50^{\circ} \mathrm{C}$ and with baseline counter GDE cathodes which had a loading of approximately $3 \mathrm{mg} / \mathrm{cm}^{2}$ of the same Pt material.

\section{Discussion}

\subsection{Challenges of electrolysis electrodes}

Electrolysis electrodes present additional challenges vs. fuel cell electrodes, due to the high operating potentials, high differential pressures, and the physical stresses on the electrode layer due to the turbulent bubbling at the gas evolution electrodes. While the 
electrolysis catalyst layers do not undergo relative humidity cycling or typically freeze-thaw cycles, the operating potential is well above the open circuit voltage on the oxygen side of the cell. Therefore, the anode catalyst and catalyst support material options are severely limited, since carbon cannot be used as a support and few other materials are sufficiently conductive or stable at $2 \mathrm{~V}$ in acidic media. Electrolysis electrodes also require different water management strategies, since the electrode needs to be fully wet at all times, in contrast to the fuel cell.

\subsection{Core shell activity}

In catalysis, the binding energy of an adsorbate to a metal surface is largely dependent on the electronic structure (Pt is dominated by the valence d-band density of states) of the surface: a good indirect measure of the bonding strength is the location of the Pt d-band center. Optimal binding, for the fastest reaction rate, between a metal surface and a reactant requires a balance between too strong an adherence of the adsorbate (causing a prolonged blocking of the active site) and too loose an interaction (reducing the time necessary for the electron transfer resulting in product conversion). Strong interaction of the support with Pt clusters requires electron transfer between the two. This transfer shifts the d-band center of Pt to higher binding energies. This transfer weakens the bonding between $\mathrm{Pt}$ and $\mathrm{O}_{2}$ adsorbates while also providing a covalent anchoring site. The most promising near term electrocatalysts for the oxygen reduction reaction (ORR) appears to be the Pt-based bimetallic systems, and it is likely that these will be used in electric vehicles in the future. However, core-shell catalyst structures, having a shell thickness of only a few layers, have garnered enormous attention because they simultaneously reduce cost and tune catalyst activity. A core-shell catalyst's ORR activity is modified because the core material shifts the electronic structure at the surface of the active shell material ${ }^{39,40}$. Core nanoparticles of $\mathrm{Pd}, \mathrm{Pd}-\mathrm{Ru}$, and $\mathrm{Pd}$ supported on an amorphous carbon are deposited, by a 
RSDT, onto glassy carbon rotating disk electrodes and gas diffusion layers. A Pt monolayer was deposited using galvanic displacement of an under potentially deposited Cu monolayer with Pt. The Pt monolayer is then tested to determine the electrochemical surface area and activity toward the oxygen reduction reaction. Depositions of the Pd core were applied at substrate temperatures of $250^{\circ} \mathrm{C}$ and $150^{\circ} \mathrm{C}$. A PtML/ $\mathrm{Pd}\left(250^{\circ} \mathrm{C}\right)$ has higher Pt mass and specific ORR activities than $\mathrm{PtML} / \mathrm{Pd}\left(150^{\circ} \mathrm{C}\right)$. This is due to smoother surface of $\mathrm{Pd}\left(250^{\circ} \mathrm{C}\right)$ compared to $\mathrm{Pd}\left(150^{\circ} \mathrm{C}\right)$. During membrane electrode assembly testing in $\mathrm{O}_{2}$, the Pt mass activity was $0.532 \mathrm{~A} / \mathrm{mg} \mathrm{Pt}$ at $0.9 \mathrm{~V}$. The voltage at $1 \mathrm{~A} / \mathrm{cm}^{2}$ was $0.613 \mathrm{~V}$, and a peak power density of $0.93 \mathrm{~W} / \mathrm{cm}^{2}$ was achieved.

\subsection{Status of core shell and RSDT in electrolysis}

While there is still optimization and manufacturing development to be done, study of core shell catalysts have shown the scalability of the synthesis, and enhanced activity for hydrogen evolution. At low loadings, the core shell catalysts show improved performance over the baseline catalyst at the same reduced loadings using the same manufacturing techniques, indicating the unique properties of these materials. To date, the core shell catalysts have been limited to the GDE configuration in electrolyzers due to current manufacturing capability. Depositing the catalyst on the gas diffusion layer essentially provides a well distributed conductive matrix as a support for the catalyst, which compensates for manufacturing limitations.

At the same time, improved processing techniques such as RSDT to deposit uniform, high surface area catalyst layers can achieve similar reductions in loading. RSDT also introduces additional flexibility in electrode configuration, enabling either the GDE or CCM. Additional studies are ongoing in order to tailor the deposition parameters for the anode, but early performance data indicates the potential to meet the baseline target with much 
lower catalyst loading. This result is promising since the oxygen evolution catalyst has much lower exchange current density than the hydrogen evolution catalyst, yet reductions in loadings to reach values which would eliminate catalyst cost as a roadblock to energy cost targets appear feasible.

Combining these two advancements could open a large parameter space for optimization of catalyst loading in PEM electrolyzer cells. Core shell catalysts deposited via RSDT have not yet been tested in electrolysis cells, but it has been demonstrated that RSDT conditions can be tuned to form core shell structures. As both technologies advance, leveraging these synergies may help to accelerate progress, especially since RSDT can be adapted to roll to roll processing. As part of the current collaboration, a scaled up RSDT system is currently under design. Energy analysis has also shown that RSDT can produce electrodes at scale with lower energy than current fabrication methods.

\section{Conclusions}

Core shell catalysts have been demonstrated to show enhanced activity in both fuel cells and electrolyzer cells. For electrolysis, as shown in this paper, there is considerable potential for reduction in catalyst loading and PGM usage. A key component of increasing catalyst mass activity is manufacturing. In separate experiments from the core shell investigations, spray pyrolysis/RSDT has shown the ability to highly disperse catalyst powders and provide electrochemical access to the majority of the catalyst surface. RSDT has also been shown to have the ability to form core shell structures in situ, although this method has not yet been tested for electrolysis. Integrating these advancements could provide a pathway for optimization of loading without performance impact, reducing the overall cost of renewable hydrogen. 
Acknowledgments: Research reported in this publication was supported by the Office of Energy Efficiency and Renewable Energy under award number DE-SC0008251, and the Advanced Manufacturing Office of the Department of Energy under award number DESC0009213. The content is solely the responsibility of the authors and does not necessarily represent the official views of the Department of Energy. ${ }^{41}$ 


\section{References:}

[1] Y.C. Hsieh, Y. Zhang, D. Su, V. Volkov, R. Si, L.J. Wu, Y.M. Zhu, W. An, P. Liu, P. He, S.Y. Ye, R.R. Adzic, J.X. Wang, Ordered bilayer ruthenium-platinum core-shell nanoparticles as carbon monoxide-tolerant fuel cell catalysts, Nat. Commun., 4 (2013) 9.

[2] J.X. Wang, Y. Zhang, C.B. Capuano, K.E. Ayers, Ultralow charge-transfer resistance with ultralow Pt loading for hydrogen evolution and oxidation using Ru@Pt core-shell nanocatalysts, Sci. Rep., 5 (2015).

${ }^{1}$ http://www.hydrogennet.dk/fileadmin/user_upload/PDF-

filer/Aktiviteter/Kommende_aktiviteter/Elektrolysesymposium/Raymond_Schmid_Hygrogenics_120510_Co penhagen_Symposium_Final.pdf

2http://www.fch.europa.eu/sites/default/files/2\%20Water\%20Electrolysis\%20Status\%20and\%20Potential \%20for\%20Development.pdf

3 . Bockris, J. O. M., Conway, B., E., Yeager, E., and White, R. E., Comprehensive Treatise of Electrochemistry. New York: Plenum Press, 1981.

${ }^{4}$ Ayers, K. E., Anderson, E. B., Capuano, C., Carter, B., Dalton, L., Hanlon, G., Manco, J., and Niedzwiecki, M.; ECS Trans., 33 (1), 3-15 (2010)

${ }^{5}$ Ayers, K. E., Anderson, E. B., Dreier, K., and Harrison, K. W., ECS Trans., 50 (49), 35-46 (2013).

${ }^{6}$ http://www.hydrogen.energy.gov/pdfs/review12/pd071_ayers_2012_o.pdf

7 Brankovic, S. R., Wang, J. X. \& Adzic, R. R. Electrochem. Solid State Lett., 4, A217-A220 (2001).

${ }^{8}$ Sasaki, K., Wang, J.X., Balasubramanian, M., McBreen, J., Uribe, F., Adzic, R.R., Electrochim. Acta, 49 (2004)

3873-3877

${ }^{9}$ Wang, J. X., Brankovic, S. R., Zhu, Y., Hanson, J. C. \& Adzic, R. R. J. Electrochem. Soc., 150, A1108-A1117 (2003).

${ }^{10}$ Adzic, R. R., Zhang, J., Sasaki, K., Vukmirovic, M. B., Shao, M., Wang, J. X., Nilekar, A. U., Mavrikakis, M., Uribe, F., Top. Catal., 46 (2007) 249-262.

${ }^{11}$ Brankovic, S.R., Wang, J.X., and Adzic, R.R., Surf. Sci., 474 (2001) L173-179. 
12 Wang, J. X., Inada, H., Wu, L., Zhu, Y., Choi, Y., Liu, P., Zhou, W., and Adzic, R. R., J. Am. Chem. Soc., 131 (2009) 17298-17302.

${ }^{13}$ Chen, S.; Ferrira, P. J.; Sheng, W.; Yabuuchi, N.; Allard, L.; Shao-Horn, Y., J. Am. Chem. Soc., 130, 2008, 13818. ${ }^{14}$ Stamenkovic, V. R.; Fowler, B.; Mun, B. S.; Wang, G. F.; Ross, P. N.; Lucas, C. A.; Markovic, N. M., Science, 315, $2007,493$.

${ }^{15}$ Stamenkovic, V. R.; Mun, B. S.; Arenz, M.; Mayrhofer, K. J. J.; Lucas, C. A.; Wang, G.; Ross, P. N.; Markovic, N. M., Nature Mater., 6, 2007, 241.

${ }^{16}$ Strasser, P. et al., Nat. Chem. 2, 454-460 (2010).

17 Srivastava, R.; Mani, P.; Hahn, N.; Strasser, P., Angew. Chem. Int. Ed. 46 2007, 8988.

${ }^{18}$ Nørskov, J. K.; Rossmeisl, J.; Logadottir, A.; Lindqvist, L.; Kitchin, J. R.; Bligaard, T.; Jónsson, H., J. Phys. Chem. $B, \mathbf{1 0 8}, 2004,17886$.

${ }^{19}$ Skulason, E., Tripkovic, V., Bjorketun, M. E., Gudmundsdottir, S., Karlberg, G., Rossmeisl, J., Bligaard, T., Jonsson, H., and Norskov, J. K., J. Phys. Chem. C, 114, 2010, 22374.

${ }^{20}$ Hartmann, H., Diemant, T., Bansmann, J. and Behm, R. J., Phys. Chem. Chem. Phys. 14, 10919-10934 (2012).

${ }^{21} \mathrm{Yu}$, H., Roller, J.M., Mustain, W.E., Maric, R., Journal of Power Sources, 283, 84-94 (2015).

22 Roller, J. M., Yu, H., Vukmirovic, M., Bliznakov, S., Kotula, P. G., Carter, C. B., Adzic, R., \& Maric, R., Electrochimica Acta, 138, 341-352 (2014).

${ }^{23}$ Roller, J. M., Renner, J., Yu, H., Capuano, C., Kwak, T., Wang, Y., Carter, C. B., Ayers, K., \& Maric, R., J. Power Sources, 271, 366-376 (2014)

${ }^{24}$ Hsieh, Y.-C., Zhang, Y., Su, D., Volkov, V., Si, R., Wu, L., Zhu, Y., An, W., Liu, P., He, P., Ye, S., Adzic, R. R., and Wang, J. X., Nat. Commun. 4, 2466 (2013) .

${ }^{25}$ Roller, J.M., Arellano-Jimenez, M.A., Jain, R., Yu, H., Carter, C.B., and Maric, R., J. Electrochem. Soc., 160 (2013) F716-F730.

${ }^{26}$ Roller, J.M., Arellano-Jiménez, M.J., Yu, H., Jain, R., Carter, C.B., Maric, R., Electrochim. Acta, 107 (2013) 632655.

${ }^{27}$ Yu, H., Roller, J.M., Kim, S., Wang, Y., Kwak, D., Maric, R., J. Electrochem. Soc. 161 (2014) F622-F627. 
${ }^{28}$ Roller, J., Renner, J., Yu, H., Capuano, C., Kwak, T., Wang, Y., Carter, C.B., Ayers, K., Mustain, W.E., Maric, R. J. Power Sources, 271 (2014) 366-376.

${ }^{29}$ Yu, H., Roller, J.M., Mustain, W.E., Maric, R., J. Power Sources, 283 (2015) 84-94.

30 Roller, J.M., Arellano-Jimenex, M.J., Yu, H., Jain, R., Carter, C.B., and Maric, R. Electrochim. Acta, $107632-655$ (2013).

3115 V. Yang, Modeling of supercritical vaporization, mixing, and combustion processes in liquid-fueled propulsion systems, Proceedings of the Combustion Institute 28 (2000) 925-942.

32 Zhao, S., et al. Stability and Activity of Pt/ITO Electrocatalyst for Oxygen Reduction Reaction in Alkaline Media, Electrochimica Acta 157 (2015) 175-182.

33 Zhao, S., Yu, H., Maric, R., Danilovic, N., Capuano, C. B., Ayers, K. E., and Mustain, W. E., Calculating the Electrochemically Active Surface Area of Iridium Oxide in the Application of Proton Exchange Membrane Electrolyzers, J. Electrochem. Soc., accepted for publication.

${ }^{34}$ Lyons, M.E.G. and Floquet, S. Phys. Chem. Chem. Phys., 13, 2011, 5314-5335.

35 Puthiyapura et al. Int. J. Hydrogen Energy, 2014, 39, 1905

${ }^{36}$ Siracusano et al. Appl. Catal., B: 2015, 164, 488

37 Xu et al. Electrochimica Acta, 2012, 59, 105

38 Puthiyapura et al. J. Power Sources, 2014, 269, 451

${ }^{39}$ Stamenkovic, V., Mun, B., Mayrhofer, K., Ross, P., Markovic, N., Rossmeisl, J., Greeley, J., Norskov, J., Angew. Chem.,118 (18) (2006) 2963.

${ }^{40}$ Roller, J., Yu, H., Vukmirovic, M.B., Bliznakov, S., Kotula, P.G., Carter, C.B., Adzic R.R., Maric, R., Electrochim. Acta 138 (2014) 341-352. 


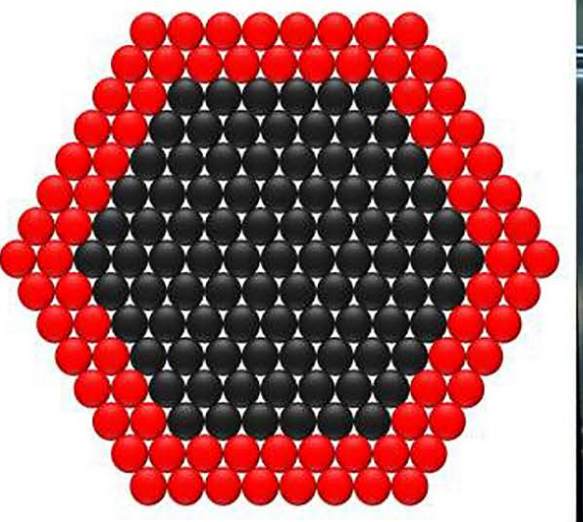

graphical abstract

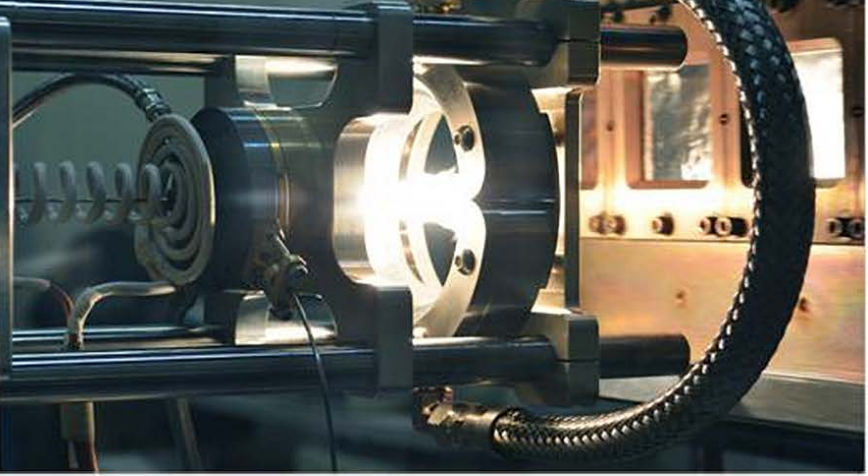

